\title{
7SK Small Nuclear RNA
}

National Cancer Institute

\section{Source}

National Cancer Institute. 7SK Small Nuclear RNA. NCI Thesaurus. Code C95951.

A small nuclear RNA encoded by the human RN7SK gene. This olig oribonucleotide may play a role in the regulation of the enzymatic activity of RNA polymerase II. 